\title{
DETEKSI KEBERADAAN Phytophthora spp. DI AIR
}

Detection of Phytophthora spp existence in water

\author{
Purnamila Sulistyawati \\ Balai Besar Penelitian Bioteknologi dan Pemuliaan Tanaman Hutan \\ Jl. Palagan Tentara Pelajar Km 15, Purwobinangun, Pakem, Sleman, Yogyakarta 55582 \\ e-mail: purnamila_mila@yahoo.com
}

\begin{abstract}
The genus of Phytophthora is a destructive plants pathogen. However the existence of these species in plant tissue was hardly to detect because the fungus may also be present as resistant propagules in soil or spread through waterways. This study aimed to test the FTA card as a direct bait to obtain the DNA of Phytophthora spp and also to investigate the suitability of FTA card as a sampling method. This research used several Phytophthora baits including FTA card followed by DNA extraction and PCR used ITS primers and genus/species specific primers. The result of the study showed that FTA card can be used as a direct bait for Phytophthora spp. and to sample fungal DNA from other Phytophthora baits. However, further optimisation and validation are still required.
\end{abstract}

Key words : Phytophthora, FTA Card, Baits, PCR

\begin{abstract}
ABSTRAK
Genus Phytophthora merupakan salah satu patogen tanaman yang destruktif. Namun deteksi keberadaan Phytophthora pada jaringan tanaman seringkali susah dilakukan karena spesies ini dapat berbentuk sebagai propagul resisten di tanah atau tersebar melalui aliran air. Penelitian ini bertujuan untuk melakukan pengujian terhadap kartu FTA baik sebagai umpan langsung untuk memperoleh DNA Phytophthora spp. langsung dari air mengalir ataupun sebagai alat untuk mengikat DNA Phytophthora spp yang diperoleh dari umpan. Hasil penelitian ini menunjukkan bahwa melalui pengujian menggunakan primer ITS1F/ITS4, ITS1/ITS2 dan beberapa primer spesifik genus/spesies, kartu FTA terbukti dapat mengikat DNA jamur langsung dari air dan dari bagian tanaman umpan yang terinfeksi jamur. Meskipun demikian, optimalisasi dan validasi mendalam tetap harus dilakukan.
\end{abstract}

\section{Kata kunci: Phytophthora, Kartu FTA, umpan, PCR}

\section{PENDAHULUAN}

Phytophthora adalah salah satu genus "water mold" dari kelas Oomycetes. Siklus hidup Phytophthora spp. biasanya bergantung pada adanya air bebas di tanah. Phytophthora mempunyai zoospore berflagel yang dapat dengan mudah menyebar melalui aliran air (Ristaino dan Gumpertz, 2000) dan mempunyai spora istirahat yang berdinding tebal (chlamydospora) yang berguna untuk bertahan hidup pada kondisi yang tidak menguntungkan. 
Menurut Tyler (2002), semua species dari genus Phytophthora merupakan patogen yang destruktif, menyebabkan kebusukan pada akar, batang, daun dan buah. Gejala penyakit tanaman akibat terserang Phytophthora adalah damping-off pada bibit, nekrosis di tanaman keras, pengerdilan dan pembusukan serta perubahan warna pada stele dan korteks.

Phytophthora diyakini sebagai patogen yang secara signifikan menyebabkan penyakit akar pada tanaman berkayu, menyebabkan busuk collar, kanker dan infeksi daun (Brasier dkk., 2004; Duran dkk., 2008). Phytophthora sebagai patogen penyebab busuk akar tumbuh melalui sistem perakaran dan batang pada suatu tanaman.

Gejala pertama yang terlihat adalah layu dan dedaunan menguning. Dedaunan kemudian mengering dan akar membusuk. Tanaman yang terinfeksi biasanya mati karena kekurangan air dan nutrisi, meskipun beberapa dapat bertahan hidup.

Pengetahuan tentang distribusi penyebaran Phytophthora spp. sangat penting untuk pengelolaan tanah secara efektif. Namun demikian identifikasi keberadaan Phytophthora pada jaringan tanaman akan sangat sulit karena jamur ini kemungkinan juga akan berbentuk sebagai propagul resisten di tanah atau tersebar melalui aliran air, sehingga deteksi keberadaan jenis patogen ini menjadi sangat penting.

Cara pendeteksian termasuk menumbuhkan jamur ini pada beberapa tipe umpan dan kemudian menanam umpan tersebut pada media agar yang sesuai untuk mendorong terjadinya sporulasi. Pengumpanan tidak terlalu sering digunakan untuk mendeteksi species Phytophthora pada suatu jaringan inang tetapi lebih sesuai untuk isolasi dari sampel tanah dan air.

Zoospora akan menyerang materi umpan, namun demikian Mc Carren dkk., (2005) berpendapat bahwa kemampuan Phytophthora untuk bertahan hidup sebagai dorman di tanah dapat menyebabkan patogen tersebut tetap tidak terdeteksi keberadaannya.

Umpan yang telah terinfeksi (misalnya akar atau bagian tanaman lainnya) akan dicuci. Bercak bercak yang ada akan diambil dan dikulturkan pada suatu media agar khusus Phytophthora yang telah ditambahkan rifampicin dan ampicillin (Gevens dkk., 2007) untuk keperluan identifikasi morfologi atau pengujian DNA molekuler. 
Beberapa media agar khusus Phytophthora diantaranya adalah P10, PARPH-V8 dan CMA (Ferguson dan Jeffers, 1999; Jeffers dan Martin 1986; Tsao, 1970).

Teknik isolasi Phytophthora spp. dari air telah mengalami banyak perkembangan (Britt dan Hansen, 2009; Ghimire dkk., 2006; Ghimire dkk., 2009; Hong dkk., 2008; Steddom, 2009). Teknik ini termasuk pengumpanan, penyaringan, sentrifugasi sampel air, menanam umpan pada media selektif khusus untuk deteksi atau penggunaan teknik molekuler untuk mendeteksi Phytophthora langsung dari umpan, saringan atau pellet hasil sentrifugasi.

Beberapa tahun terakhir telah terjadi peningkatan aplikasi teknik molekuler untuk mendeteksi jenis jenis Phytophthora. Pengurutan basa DNA (sekuensing) atau PCR spesies spesifik sering digunakan untuk identifikasi morfologi biakan murni Phytophthora. PCR spesies spesifik biasanya membutuhkan kemampuan penguasaan pengetahuan taksonomi yang memadai.

Kecepatan dan keakuratan deteksi dapat ditingkatkan jika PCR dan/atau sekuensing dilakukan pada DNA yang diekstraksi langsung dari umpan daripada hanya bergantung pada biakan murni
(Sechler dkk., 2009). Disamping itu terdapat potensi pengikatan langsung DNA dari materi umpan menggunakan kartu FTA (Whatman International Ltd ) atau bahkan menggunakan kartu FTA sebagai umpan.

Kartu FTA adalah alternatif yang potensial pengambilan sampel DNA karena kertas FTA mengandung bahan chelators, denaturants, dan perangkap radikal bebas yang mampu menghambat enzim, mikroba dan bahan kimia yang dapat menurunkan DNA atau RNA dalam sampel jamur.

Hal ini memungkinkan asam nukleat untuk disimpan pada suhu kamar untuk jangka waktu yang lama pada kartu FTA (Rogers dan Burgoyne, 1997). Aplikasi kartu FTA untuk sampling DNA jamur yang terkait dengan penyakit tanaman dan hutan ini juga telah dilakukan (Suzuki dkk., 2006).

Tulisan ini akan memaparkan pengujian kartu FTA sebagai umpan untuk memperoleh DNA Phytophthora spp. langsung dari air mengalir. Kartu FTA belum pernah dipakai untuk mendeteksi keberadaan Phytophthora spp. atau untuk mengikat DNA langsung dari air. Jika ini berhasil, maka DNA dapat dianalisa menggunakan beberapa protokol PCR spesies-spesifik untuk identifikasi patogen. 


\section{BAHAN DAN METODE}

\section{A. Bahan}

Bahan spesifik yang digunakan pada penelitian ini adalah umpan Phytophthora yaitu daun Fragaria sp. (strawberry), Rhododendron sp., Citrus limon (lemon), Camellia sp., Saintpaulia sp. (African violet), Eucalyptus sp., Cupressus sempervirens (pencil pine) dan Pseudotsuga menziesii (Douglas Fir); kelopak bunga Rosa sp., kecambah Phaseolus mungo (kacang hijau), Medicago sativa (Alfalfa), buah Malus sp. (apel) dan Persea americana (alpukad). Beberapa biakan Phytophtora spp. (Tabel 1, Gambar 1), diperoleh dari danau Pine, Tasmania, digunakan sebagai kontrol.

Tabel 1. Daftar biakan Phytophthora spp.

\begin{tabular}{ll}
\multicolumn{1}{c}{ Kode } & \multicolumn{1}{c}{ Species } \\
\hline PC & Phytophthora cinnamomi \\
NY 001 & Phytophthora cryptogea \\
Hansen 133 & Phytophthora drechsleri \\
Hansen 139 & Phytophthora drechsleri \\
Hansen 266 & Phytophthora drechsleri \\
P 501 & Phytophthora gonapodyides \\
S 5 & Phytophthora gonapodyides \\
S 42 & Phytophthora gonapodyides \\
\hline
\end{tabular}

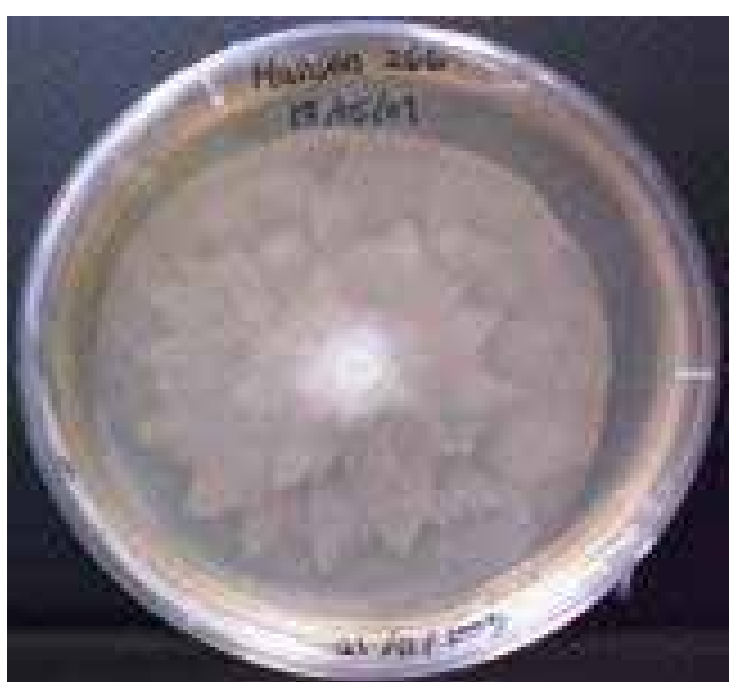

Gambar 1. Biakan Phytophthora Hansen 266 (Phytophthora drechsleri)

\section{B. Metode}

1. Persiapan umpan

Umpan, termasuk kartu FTA, dimasukkan kedalam kompartemen terpisah terbuat dari jala yang dijahit kemudian ditinggalkan di sungai South Esk selama seminggu . Beberapa Phytophthora spp. sebelumnya telah diisolasi dari aliran ini (Wardlaw, pers. comm).

Setelah seminggu, kompartemen tersebut diambil dan bagian masing-masing umpan ditanam ke media agar selektif untuk Phytophthora spp. yaitu P10 (Tsao, 1970) dan PARPH (Ferguson dan Jeffers, 1999; Jeffers dan Martin 1986).

Setelah 3 hari inkubasi, miselium jamur kemudian disubkultur ke media agar V8- PARPH dan CMA (Difco). Sebagian 
kecil dari setiap umpan juga diaplikasikan langsung ke kartu FTA dan sebagian lainnya lagi diekstraksi menggunakan metode glassmilk.

2. Metode ekstraksi DNA glassmilk

Metode glassmilk (Glen dkk., 2002) digunakan sebagai metode ekstraksi DNA dasar untuk sampel jamur dan daun. Semua sampel ditimbang sebanyak 20-30 mg, digerus menggunakan mortar dan pestle (Pellet Pestle Kontes Motor) lalu dimasukkan ke dalam tabung microcentrifuge ukuran 1,5 mL.

Buffer ekstraksi (Raeder dan Broda, 1985) ditambahkan $(250 \mu \mathrm{L})$ dan sampel diinkubasi dalam penangas air (Grant Instrumen Cambridge Ltd Tipe 20) pada suhu $65^{\circ} \mathrm{C}$ selama 1 jam. Setelah itu sampel disentrifugasi (Sigma 1-13 B. Braun Biotech International) pada kecepatan $14000 \mathrm{rpm}$ selama 15 menit. Tahapan selanjutnya adalah menyiapkan tabung microcentrifuge ukuran 1, $5 \mathrm{~mL}$ yang bersih. Sebanyak 7 $\mu \mathrm{L}$ glassmilk (Boyle dan Lew, 1995), 800 $\mu \mathrm{L} \mathrm{NaI}$ 1g/mL (BDH Kimia Australia) dan $200 \mu \mathrm{L}$ supernatan ditambahkan dimasukkan ke dalam tabung dan dicampur sampai rata menggunakan Vortex (Yellowline TTS 2-Fisher Biotech Australia).
Setelah itu tabung diinkubasi pada es selama 15 menit dan dicampur sesekali. Sampel disentrifugasi selama 10 detik, supernatan dibuang dan pelet disuspensikan dalam $800 \mu \mathrm{L}$ larutan pencuci.

Sampel disentrifugasi lagi selama 10 detik, supernatan dibuang dan pelet kembali disuspensikan menggunakan larutan Etanol 100\% (Univar-Ajax Finechem Australia, Analytical Grade) sebanyak $800 \mu \mathrm{L}$.

Sampel disentrifugasi 10 detik, supernatan dibuang dan tabung dibalik untuk dikeringkan. Pelet kemudian disuspensikan dalam TE buffer sebanyak 25 $\mu \mathrm{L}$ dan diinkubasi pada suhu $45^{\circ} \mathrm{C}$ selama 10 menit sebelum disentrifugasi pada kecepatan 14.000 rpm selama 1-2 menit. Supernatan dipindahkan ke tabung 1,5 mL dan pengenceran 1/20 dilakukan sebelum sampel digunakan untuk PCR.

3. Persiapan pengambilan sampel menggunakan kartu FTA

Sampel kecambah, buah dan daun digerus menggunakan mortar dan pestle dengan bantuan nitrogen cair. Sampel tersebut kemudian dicampur dengan larutan buffer ekstraksi DNA sampai merata dan diinkubasi pada suhu kamar (30-60 menit) sebelum kemudian dipipet dan diaplikasikan ke kartu FTA. 
Jenis lain dari sampel seperti bahan jamur dan umpan bagian tanaman terinfeksi dipotong-potong kecil diaplikasikan langsung ke kartu kemudian dikeringkan selama minimum satu jam pada suhu ruang.

Setelah berbagai sampel diterapkan pada kartu FTA, kartu diletakkan di atas matras pemotongan dan dipotong menggunakan 2.0 mm Harris Micro. Kemudian potongan kartu FTA tersebut dipindahkan ke dalam tabung mikrosentrifuge ukuran $1.5 \mathrm{~mL}$.

Untuk masing-masing tabung ditambahkan $200 \mu \mathrm{L}$ larutan FTA. Tabung kemudian ditutup, dibolak balik dan diinkubasi selama 4-5 menit pada suhu kamar. Larutan FTA diambil dengan pipet kemudian sebanyak mungkin dibuang tanpa menghilangkan sampel kartu FTA yang ada didalamnya.

Langkah ini diulang untuk total dua kali pencucian menggunakan larutan FTA. Langkah selanjutnya adalah penambahan $200 \mu \mathrm{L}$ larutan buffer TE ke masing masing tabung berisi sampel kartu FTA. Setelah itu, tabung tersebut ditutup, dibolak balik kemudian diinkubasi selama 4-5 menit pada suhu kamar. Buffer TE dibuang menggunakan pipet.
Langkah ini diulangi untuk dua kali pencucian menggunakan larutan buffer TE. Sampel kartu dikeringkan selama satu jam pada suhu kamar atau selama 20 menit pada $56^{\circ} \mathrm{C}$ sebelum disimpan pada suhu $4^{\circ} \mathrm{C}$ atau $-20^{\circ} \mathrm{C}$.

Primer yang digunakan dalam penelitian ini meliputi primer ITS1F, C T T G G T CAT T TA GA G GAA GTA A (Gardes and Bruns, 1993), primer ITS1 (TCCGTAGGTGAACCTGCGG), ITS2 (GCTGCGTTCTTCATCGATGC) dan ITS4 (TCCTCCGCTTATTGATATGC)(White dkk., 1990).

Beberapa primer spesifik spesies atau genus - spesifik (O’Brien, 2008; Schena dkk., 2008; Schena dkk., 2006) juga digunakan (Tabel 2). PCR dilakukan menggunakan thermocycler PTC-100TM (MJ Research Inc USA).

Program yang digunakan terdiri dari denaturasi awal pada $95^{\circ} \mathrm{C}$ selama 2 menit; 35 siklus $94^{\circ} \mathrm{C}$ selama 30 detik, $58^{\circ} \mathrm{C}$ selama 45 detik dan $72^{\circ} \mathrm{C}$ selama 30 detik; dan ekstensi akhir pada suhu $72^{\circ} \mathrm{C}$ selama 10 menit (Schena dkk., 2008).

PCR dilakukan pada tiga ulangan untuk semua sampel DNA baik dari ekstraksi DNA glassmilk dan kartu FTA. PCR amplifikasi 
Tabel 2. Daftar primer spesifik species dan genus

\begin{tabular}{lcc}
\hline \multicolumn{1}{c}{ Species Target } & Primer & Sekuens (5'-3') \\
\hline \multirow{2}{*}{ Phytophthora spp. } & YPh1F & CGACCATKGGTGTGGACTTT \\
& YPh2R & ACGTTCTCMCAGGCGTATCT \\
& YMeg1F & TCTGCTCTTCCGACTTGGTC \\
& YMeg2R & TGGCATTAGTTAGTTTCGTCCA \\
\hline
\end{tabular}

dilakukan dalam $50 \mu \mathrm{L}$ volume campuran reaksi yang mengandung $5 \mu \mathrm{L} 10 \mathrm{X}$ buffer reaksi (BioLine), $2 \mathrm{mM} \mathrm{MgCl}_{2}$ (BioLine), 0,2 mg/mL Bovine Serum Albumin (Fisher Biotech Australia), 0,2 mM dNTP (BioLine), 0,2 $\mathrm{mM}$ masing-masing primer, 0,05 U/ L Biotaq DNA polymerase (BioLine), $10 \mathrm{uL}$ template DNA atau satu potongan kecil (2 $\mathrm{mm}^{2}$ ) bersih sampel kartu FTA dan air (air steril, Astra Zeneca, US).

\section{HASIL DAN PEMBAHASAN}

\section{A. Isolasi jamur dari umpan}

Buah apel dan alpukad yang digunakan sebagai umpan Phytophthora hilang dimakan binatang air. Dari 11 umpan yang tersisa, didapatkan 10 biakan yang diduga Phytophthora (Tabel 3). Tidak ada biakan jamur yang didapatkan dari umpan daun Eucalyptus. Semua biakan disubkulturkan pada media CMA dan V8.

Sejumlah kecil biakan diaplikasikan langsung pada kartu FTA dan sebagian lainnya diekstraksi menggunakan metode glassmilk. Semua sampel biakan diuji dengan PCR menggunakan pasangan primer ITS1F/ITS4 dan ITS1/ITS2. Hasil PCR dari ekstraksi DNA dan aplikasi kartu FTA hampir semuanya teramplifikasi/positif (Tabel 3), meskipun efisiensi amplifikasi bervariasi dari sampel kartu FTA (Gambar 2). 
Tabel 3. Amplifikasi PCR menggunakan primer ITS1F/ITS4 dan ITS1/ITS2 pada sampel biakan Phytophthora dan biakan jamur yang diperoleh dari umpan.

\begin{tabular}{|c|c|c|c|c|c|}
\hline \multirow{3}{*}{ Kode } & \multirow{3}{*}{ Spesies } & \multicolumn{4}{|c|}{ Amplifikasi PCR ${ }^{1}$} \\
\hline & & \multicolumn{2}{|c|}{$\begin{array}{c}\text { Ekstraksi DNA } \\
\text { Glassmilk }\end{array}$} & \multicolumn{2}{|c|}{ Aplikasi Kartu FTA } \\
\hline & & $\begin{array}{l}\text { ITS1-F } \\
\text { ITS4 }\end{array}$ & $\begin{array}{l}\text { ITS1 } \\
\text { ITS2 }\end{array}$ & $\begin{array}{c}\text { ITS1-F } \\
\text { ITS4 }\end{array}$ & $\begin{array}{l}\text { ITS1 } \\
\text { ITS2 } \\
\end{array}$ \\
\hline $\mathrm{PC}$ & Phytophthora cinnamomi & $\mathbf{P}$ & $\mathbf{P}$ & $\mathbf{P}$ & $\mathbf{P}$ \\
\hline NY 001 & Phytophthora cryptogea & $\mathbf{P}$ & $\mathbf{P}$ & $\mathrm{N}$ & $\mathbf{P}$ \\
\hline Hansen 133 & Phytophthora drechsleri & $\mathrm{N}$ & $\mathbf{P}$ & $\mathrm{N}$ & $\mathrm{N}$ \\
\hline Hansen 139 & Phytophthora drechsleri & $\mathbf{P}$ & $\mathbf{P}$ & $\mathbf{P}$ & $\mathbf{P}$ \\
\hline Hansen 266 & Phytophthora drechsleri & $\mathrm{N}$ & $\mathbf{P}$ & $\mathrm{N}$ & $\mathrm{N}$ \\
\hline P 501 & Phytophthora gonapodyides & $\mathrm{N}$ & $\mathrm{N}$ & $\mathrm{N}$ & $\mathrm{N}$ \\
\hline S 5 & Phytophthora gonapodyides & $\mathrm{N}$ & $\mathbf{P}$ & $\mathrm{N}$ & $\mathrm{N}$ \\
\hline S 42 & Phytophthora gonapodyides & $\mathrm{N}$ & $\mathrm{N}$ & $\mathrm{N}$ & $\mathbf{P}$ \\
\hline IAF & Biakan dari daun Saintpaulia sp. & $\mathrm{N}$ & $\mathrm{N}$ & $\mathrm{N}$ & $\mathbf{P}$ \\
\hline $\mathrm{ICO}$ & Biakan dari daun Pseudotsuga menziesii & $\mathbf{P}$ & $\mathbf{P}$ & $\mathrm{N}$ & $\mathbf{P}$ \\
\hline IAL & Biakan dari kecambah Medicago sativa & $\mathbf{P}$ & $\mathbf{P}$ & $\mathrm{N}$ & $\mathbf{P}$ \\
\hline ILE & Biakan dari daun Citrus limon & $\mathbf{P}$ & $\mathbf{P}$ & $\mathrm{N}$ & $\mathbf{P}$ \\
\hline IPE & Biakan dari daun Cupressus sempervirens & $\mathbf{P}$ & $\mathbf{P}$ & $\mathrm{N}$ & $\mathrm{N}$ \\
\hline IRH & Biakan dari daun Rhododendron sp. & $\mathbf{P}$ & $\mathbf{P}$ & $\mathrm{N}$ & $\mathbf{P}$ \\
\hline IRO & Biakan dari kelopak bunga Rosa sp. & $\mathbf{P}$ & $\mathbf{P}$ & $\mathrm{N}$ & $\mathrm{N}$ \\
\hline IST & Biakan dari daun Fragaria & $\mathbf{P}$ & $\mathbf{P}$ & $\mathrm{N}$ & $\mathrm{N}$ \\
\hline IMB & Biakan dari kecambah Phaseolus mungo & $\mathrm{N}$ & $\mathrm{N}$ & $\mathbf{P}$ & $\mathbf{P}$ \\
\hline ICA & Biakan dari daun Camellia sp. & $\mathrm{N}$ & $\mathbf{P}$ & $\mathrm{N}$ & $\mathrm{N}$ \\
\hline
\end{tabular}

${ }^{1} \mathrm{P}$ : amplifikasi fragmen di ukuran $600 \mathrm{bp}$ (primer ITS1-F/ITS4) atau $300 \mathrm{bp}$ (primer ITS1/ITS2); N : tidak ada amplifikasi

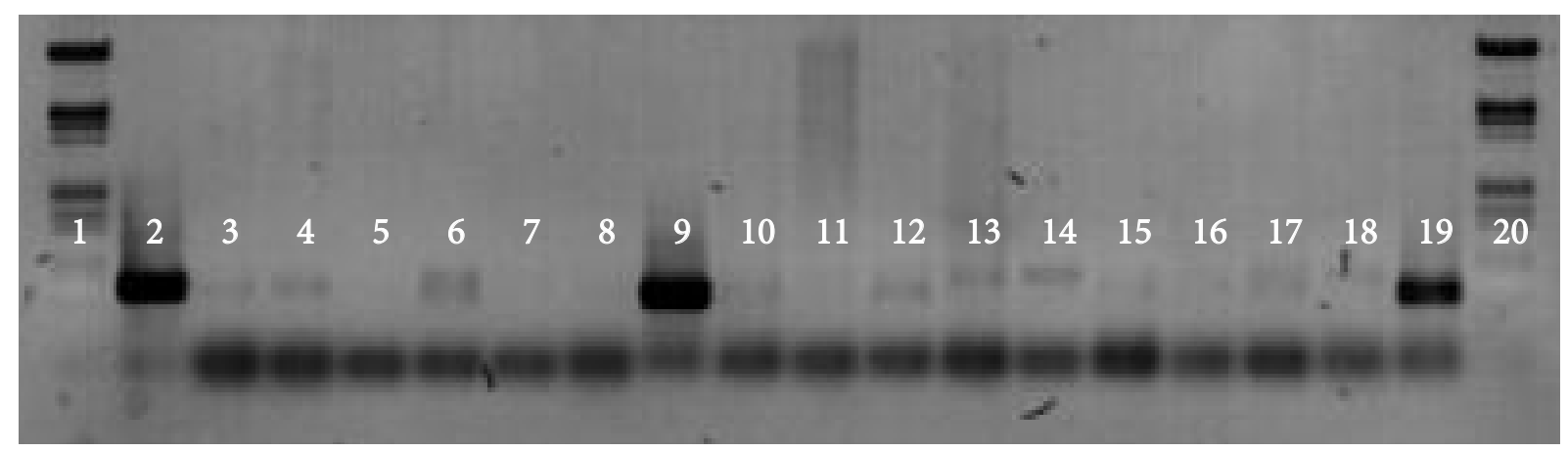

Gambar 2. Amplifikasi PCR sampel DNA biakan Phytophthora dan biakan yang didapatkan dari umpan pada kartu FTA menggunakan primer ITS-1F/ITS 4. Keterangan: 1 dan 20: DNA marker lambda DNA Eco RI dan Hind III; 2, positif kontrol; 3, S42; 4, Hansen 139; 5, Hansen 133; 6, Hansen 266; 7 , S5; 8, NY001; 9, PC; 10, IAF; 11, ICO; 12, IAL; 13, ILE; 14, P501; 15, IPE; 16, IRH; 17, IRO; 18, IST dan 19, IMB 


\section{B. PCR dari umpan}

DNA jamur yang didapatkan dari umpan dan diekstraksi langsung menggunakan metode ekstraksi glassmilk teramplifikasi sebanyak 6 sampel sedangkan DNA jamur yang diaplikasikan pada kartu FTA teramplifikasi sebanyak 3 sampel (Tabel
4). Umpan yang lunak seperti kecambah kacang hijau (Phaseolus mungo) dan daun African violet (Saintpaulia sp) memberikan hasil amplifikasi PCR yang sangat jelas. DNA jamur juga teramplifikasi dari sampel kartu FTA yang dijadikan umpan (Gambar $3)$.

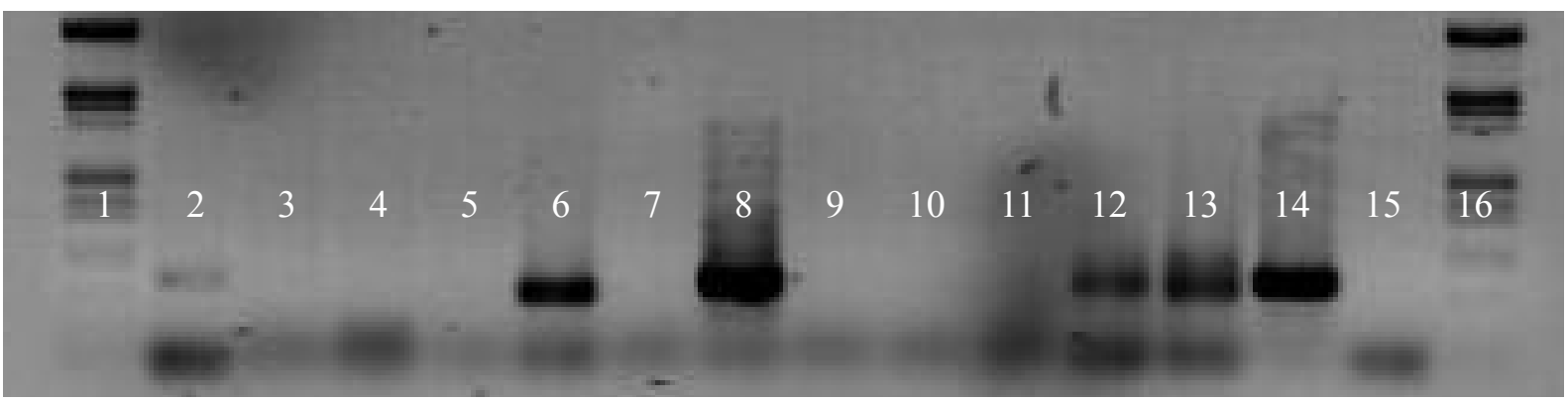

Gambar 3. Amplifikasi PCR menggunakan primer ITS1F/ITS4 dari sampel umpan yang diaplikasikan langsung ke kartu FTA dan dari sampel kartu FTA yang ditinggalka di sungai sebagai umpan. Keterangan : 1 dan 16 DNA size marker, lambda DNA Eco RI dan Hind III; 2, ICA (biakan dari daun Camellia); 3, daun Pseudotsuga menziesii; 4, daun Fragaria sp.; 5, daun Cupressus sempervirens; 6, kecambah Medicago sativa; 7, daun Rhododendron sp.; 8, kecambah Phaseolus mungo; 9, daun Citrus limon; 10, daun Camellia sp.; 11, kelopak bunga Rosa sp.; 12, daun Saintpaulia sp.; 13, kartu FTA (umpan), 14, positif kontrol; 15, negatif kontrol (tidak ada DNA).

Tabel 4. Amplifikasi PCR dari umpan menggunakan primer ITS

\begin{tabular}{|c|c|c|c|c|c|}
\hline \multirow{3}{*}{ Kode } & \multirow{3}{*}{ Sampel } & \multicolumn{4}{|c|}{ Amplifikasi PCR $^{1}$} \\
\hline & & \multicolumn{2}{|c|}{$\begin{array}{c}\text { Ekstraksi DNA } \\
\text { Glassmilk } \\
\end{array}$} & \multicolumn{2}{|c|}{ Aplikasi Kartu FTA } \\
\hline & & $\begin{array}{l}\text { ITS1F- } \\
\text { ITS4 }\end{array}$ & $\begin{array}{l}\text { ITS1- } \\
\text { ITS2 }\end{array}$ & $\begin{array}{l}\text { ITS1F- } \\
\text { ITS4 }\end{array}$ & ITS1-ITS2 \\
\hline $\mathrm{CF}$ & Daun Pseudotsuga menziesii & $\mathbf{P}$ & $\mathbf{P}$ & $\mathrm{N}$ & $\mathrm{N}$ \\
\hline SL & Daun Fragaria sp. & $\mathbf{P}$ & $\mathbf{P}$ & $\mathrm{N}$ & $\mathrm{N}$ \\
\hline PL & Daun Cupressus sempervirens & $\mathrm{N}$ & $\mathbf{P}$ & $\mathrm{N}$ & $\mathrm{N}$ \\
\hline $\mathrm{AL}$ & Kecambah Medicago sativa & $\mathrm{N}$ & $\mathbf{P}$ & $\mathbf{P}$ & $\mathrm{N}$ \\
\hline RL & Daun Rhododendron sp. & $\mathrm{N}$ & $\mathrm{N}$ & $\mathrm{N}$ & $\mathrm{N}$ \\
\hline MB & Kecambah Phaseolus mungo & $\mathbf{P}$ & $\mathbf{P}$ & $\mathbf{P}$ & $\mathbf{P}$ \\
\hline LL & Daun Citrus limon & $\mathbf{P}$ & $\mathbf{P}$ & $\mathrm{N}$ & $\mathrm{N}$ \\
\hline $\mathrm{CL}$ & Daun Camellia sp. & $\mathrm{N}$ & $\mathrm{N}$ & $\mathrm{N}$ & $\mathrm{N}$ \\
\hline $\mathrm{RP}$ & Kelopak bunga Rosa sp. & $\mathbf{P}$ & $\mathbf{P}$ & $\mathrm{N}$ & $\mathrm{N}$ \\
\hline $\mathrm{AV}$ & Daun Saintpaulia sp. & $\mathbf{P}$ & $\mathbf{P}$ & $\mathbf{P}$ & $\mathbf{P}$ \\
\hline EL & Daun Eucalyptus sp. & NT & NT & $\mathrm{N}$ & $\mathrm{N}$ \\
\hline
\end{tabular}

${ }^{1} \mathrm{P}$ : amplifikasi fragmen di ukuran $600 \mathrm{bp}$ (primer ITS1-F/ITS4) atau $300 \mathrm{bp}$ (primer ITS1/ITS2); N : tidak ada amplifikasi; NT : sampel tidak diuji menggunakan pasangan primer di atas 


\section{PCR menggunakan primer spesifik genus dan spesies}

Tujuh dari delapan biakan yang diketahui sebagai Phytophthora hasil dari ekstraksi DNA secara langsung dan aplikasi kartu FTA diuji dengan PCR memberikan hasil positif menggunakan pasangan primer
YPh1F/YPh2R (Tabel 5) dan enam dari tujuh sampel tersebut juga teramplifikasi menggunakan primer YMeg1F/YMeg2R. Hanya satu biakan dari umpan yang teramplifikasi menggunakan dua pasang primer tersebut yaitu ICO (Tabel 6).

Tabel 5. Amplifikasi PCR sampel biakan menggunakan primer spesifik genus dan spesies

\begin{tabular}{llccccc}
\hline \multirow{2}{*}{ Kode } & \multirow{2}{*}{ Nama Sampel } & \multicolumn{2}{c}{ YPh1F/YPh2R } & \multicolumn{2}{c}{ YMeg1F/YMeg2R } \\
\cline { 3 - 6 } & & DNA $^{1}$ & FTA $^{2}$ & DNA & FTA \\
\hline PC & Phytophthora cinnamomi & N & N & N & N \\
NY 001 & Phytophthora cryptogea & $\mathbf{P}$ & $\mathbf{P}$ & $\mathbf{P}$ & $\mathbf{P}$ \\
Hansen 133 & Phytophthora drechsleri & P & $\mathbf{P}$ & $\mathbf{P}$ & $\mathbf{P}$ \\
Hansen 139 & Phytophthora drechsleri & $\mathbf{P}$ & $\mathbf{P}$ & $\mathbf{P}$ & $\mathbf{P}$ \\
Hansen 266 & Phytophthora drechsleri & $\mathbf{P}$ & $\mathbf{P}$ & $\mathbf{P}$ & $\mathbf{P}$ \\
\hline
\end{tabular}

Tabel 6. Amplifikasi PCR sampel biakan menggunakan primer spesifik genus dan spesies (lanjutan)

\begin{tabular}{|c|c|c|c|c|c|}
\hline \multirow{2}{*}{ Kode } & \multirow{2}{*}{ Nama Sampel } & \multicolumn{2}{|c|}{ YPh1F/YPh2R } & \multicolumn{2}{|c|}{ YMeg1F/YMeg2R } \\
\hline & & DNA $^{1}$ & FTA $^{2}$ & DNA & FTA \\
\hline P 501 & Phytophthora gonapodyides & $\mathbf{P}$ & $\mathbf{P}$ & $\mathrm{N}$ & $\mathrm{N}$ \\
\hline S 5 & Phytophthora gonapodyides & $\mathbf{P}$ & $\mathbf{P}$ & $\mathbf{P}$ & $\mathbf{P}$ \\
\hline S 42 & Phytophthora gonapodyides & $\mathbf{P}$ & $\mathbf{P}$ & $\mathbf{P}$ & $\mathbf{P}$ \\
\hline IAF & $\begin{array}{l}\text { Biakan dari umpan daun Saintpaulia } \\
\text { sp. }\end{array}$ & $\mathrm{N}$ & $\mathrm{N}$ & $\mathrm{N}$ & $\mathrm{N}$ \\
\hline $\mathrm{ICO}$ & $\begin{array}{l}\text { Biakan dari umpan daun } \\
\text { Pseudotsuga menziesii }\end{array}$ & $\mathrm{N}$ & $\mathbf{P}$ & $\mathbf{P}$ & $\mathrm{N}$ \\
\hline IAL & $\begin{array}{l}\text { Biakan dari umpan kecambah } \\
\text { Medicago sativa }\end{array}$ & $\mathrm{N}$ & $\mathrm{N}$ & $\mathrm{N}$ & $\mathrm{N}$ \\
\hline ILE & $\begin{array}{l}\text { Biakan dari umpan daun Citrus } \\
\text { limon }\end{array}$ & $\mathrm{N}$ & $\mathrm{N}$ & $\mathrm{N}$ & $\mathrm{N}$ \\
\hline IPE & $\begin{array}{l}\text { Biakan dari umpan daun Cupressus } \\
\text { sempervirens }\end{array}$ & $\mathrm{N}$ & $\mathrm{N}$ & $\mathrm{N}$ & $\mathrm{N}$ \\
\hline IRH & $\begin{array}{l}\text { Biakan dari umpan daun } \\
\text { Rhododendron }\end{array}$ & $\mathrm{N}$ & $\mathrm{N}$ & $\mathrm{N}$ & $\mathrm{N}$ \\
\hline IRO & $\begin{array}{l}\text { Biakan dari umpan kelopak bunga } \\
\text { Rosa sp. }\end{array}$ & $\mathrm{N}$ & $\mathrm{N}$ & $\mathrm{N}$ & $\mathrm{N}$ \\
\hline IST & Biakan dari umpan daun Fragaria sp. & $\mathrm{N}$ & $\mathrm{N}$ & $\mathrm{N}$ & $\mathrm{N}$ \\
\hline IMB & $\begin{array}{l}\text { Biakan dari umpan kecambah } \\
\text { Phaseolus mungo }\end{array}$ & $\mathrm{N}$ & $\mathrm{N}$ & $\mathrm{N}$ & $\mathrm{N}$ \\
\hline ICA & Biakan dari umpan daun Camellia sp. & $\mathrm{N}$ & $\mathrm{N}$ & $\mathrm{N}$ & $\mathrm{N}$ \\
\hline
\end{tabular}

${ }^{1}$ DNA diekstraksi menggunakan metode glassmilk. ${ }^{2}$ Miselium dari biakan diaplikasikan langsung ke kartu FTA. P: amplifikasi fragmen pada ukuran 470 bp untuk primer Yph1F/Yph2R dan 196 bp untuk primer Ymeg1F/ Ymeg2R, N : tidak ada amplifikasi. 
Tabel 7. Amplifikasi PCR menggunakan primer spesifik genus dan spesies untuk DNA yang diperoleh dari umpan.

\begin{tabular}{|c|c|c|c|c|c|}
\hline \multirow{2}{*}{ Kode } & \multirow{2}{*}{ Jenis Umpan } & \multicolumn{2}{|c|}{ Yph1F/Yph2R } & \multicolumn{2}{|c|}{ YMeg1F/YMeg2R } \\
\hline & & DNA $^{1}$ & FTA $^{2}$ & DNA & FTA \\
\hline $\mathrm{CF}$ & Daun Pseudotsuga menziesii & $\mathbf{P}$ & $\mathrm{N}$ & $\mathrm{N}$ & $\mathrm{N}$ \\
\hline $\mathrm{SL}$ & Daun Fragaria sp. & $\mathbf{P}$ & $\mathbf{P}$ & $\mathrm{N}$ & $\mathrm{N}$ \\
\hline PL & Daun Cupressus sempervirens & $\mathbf{P}$ & $\mathrm{N}$ & $\mathrm{N}$ & $\mathrm{N}$ \\
\hline $\mathrm{AL}$ & Kecambah Medicago sativa & $\mathrm{N}$ & $\mathrm{N}$ & $\mathrm{N}$ & $\mathrm{N}$ \\
\hline RL & Daun Rhododendron sp. & $\mathrm{N}$ & $\mathrm{N}$ & $\mathrm{N}$ & $\mathrm{N}$ \\
\hline MB & Kecambah Phaseolus mungo & $\mathrm{N}$ & $\mathrm{N}$ & $\mathrm{N}$ & $\mathrm{N}$ \\
\hline LL & Daun Citrus limon & $\mathrm{N}$ & $\mathrm{N}$ & $\mathrm{N}$ & $\mathrm{N}$ \\
\hline CL & Daun Camellia sp. & $\mathrm{N}$ & $\mathrm{N}$ & $\mathrm{N}$ & $\mathrm{N}$ \\
\hline $\mathrm{RP}$ & Kelopak bunga Rosa sp. & $\mathrm{N}$ & $\mathrm{N}$ & $\mathbf{P}$ & $\mathrm{N}$ \\
\hline AV & Daun Saintpaulia sp. & $\mathbf{P}$ & $\mathrm{N}$ & $\mathbf{P}$ & $\mathrm{N}$ \\
\hline EL & Daun Eucalyptus sp. & $\mathrm{N}$ & $\mathrm{N}$ & $\mathrm{N}$ & $\mathrm{N}$ \\
\hline
\end{tabular}

${ }^{1}$ DNA diekstraksi menggunakan metode glassmilk. ${ }^{2}$ Miselium dari biakan diaplikasikan langsung ke kartu FTA. P: amplifikasi fragmen pada ukuran 470 bp untuk primer Yph1F/Yph2R dan 196 bp untuk primer Ymeg1F/ Ymeg2R, N : tidak ada amplifikasi.

Primer spesifik Phytophthora YPh1F/ YPh2R berhasil mengamplifikasi 4 dari 10 macam umpan yang DNA-nya diekstraksi secara langsung, dan primer YMeg1F/ YMeg2R mengamplifikasi 2 macam umpan. Adapun amplifikasi sampel umpan yang diaplikasikan ke kartu FTA belum memberikan hasil yang memuaskan (Tabel 7).

Meskipun Phytophthora spp. tidak lagi dianggap sebagai jamur dan filogeni saat ini menggolongkan OOmycetes di kingdom Stramenopila (Tyler dkk., 2006), amplifikasi dengan pasangan primer ITS1-F/ ITS4 berhasil untuk beberapa biakan Phytophthora. Primer ITS1F/ITS4 dirancang untuk mengamplifikasi DNA jamur dalam suatu DNA tanaman, meskipun demikian rangkaian lengkap rDNA ITS spesies yang dapat diamplifikasi oleh primer ini belum diketahui (Gardes dan Burns, 1993).

Beberapa PCR memberikan hasil positif menggunakan primer ITS1F/ITS4 untuk sampel DNA yang diperoleh dari umpan yang diaplikasikan ke kartu FTA. Hal ini membuktikan bahwa DNA yang terikat pada kartu FTA adalah DNA jamur karena teramplifikasi positif menggunakan pasangan primer ITS1F/ITS4. Namun demikian, DNA yang diekstraksi dari umpan menggunakan metode glassmilk 
memberikan hasil positif yang lebih besar. Sebagai tambahan, dikarenakan hasil PCR ini tidak dianalisa lebih lanjut menggunakan sekuensing maka tidak dapat dipastikan hasil tersebut adalah jamur Phytophthora spp.

Primer ITS1/ITS2 memberikan proporsi DNA teramplifikasi lebih banyak daripada primer ITS1F/ITS4 pada DNA yang terikat di kartu FTA; tetapi DNA yang teramplifikasi tersebut juga tidak dapat dipastikan sebagai jamur Phytophthora spp. Primer ITS1/ITS2 ini mengamplifikasi region yang lebih pendek daripada primer ITS1F/ITS4 sehingga amplifikasi menjadi lebih efisien. Hal ini penting apabila sampel DNA yang kita punya mempunyai konsentrasi yang rendah. Namun demikian, primer ini mempunyai kisaran target spesies yang lebih besar dan dapat mengamplifikasi DNA dari tanaman dan serangga, sehingga primer ini sangat sesuai untuk amplifikasi DNA dari suatu biakan murni.

Terdapat amplifikasi beberapa sampel yang diekstraksi langsung dan dari kartu FTA menggunakan primer jamur ITS1F/ ITS4 tapi tidak ada amplifikasi pada saat digunakan primer yang lebih umum yaitu ITS1/ITS2. Hal ini kemungkinan karena adanya hambatan PCR atau rendahnya kuantitas DNA yang terikat pada kartu FTA. Untuk kelanjutan penelitian di masa datang, pengujian hambatan PCR dan pengecekan kuantitas DNA perlu dilakukan menggunakan plasmid IAC. Hambatan PCR dan konsentrasi DNA yang rendah perlu diuji lebih lanjut untuk menemukan sebab tidak terjadinya amplifikasi DNA. Kemungkinan yang terjadi adalah kuantitas DNA yang terikat pada kartu FTA memang rendah sehingga konsentrasi DNA yang diperoleh juga kecil. Selain itu optimalisasi dan penggunaan PCR spesifik spesies di laboratorium dapat meningkatkan hasil amplifikasi DNA yang diambil dari kartu FTA.

Ketidakpastian hasil PCR yang tidak dianalisa lebih lanjut menggunakan sekuensing biasanya dapat diuji dengan melakukan PCR spesifik genus atau spesies. Adanya amplifikasi biakan Phytophthora cryptogea, P. drechslerii dan P. gonapodyides menggunakan primer yang dirancang spesifik untuk P. megasperma menunjukkan bahwa primer tersebut membutuhkan optimalisasi kondisi PCR yang lebih mendalam. Kekhususan ini cenderung dikompromikan dengan menggunakan konsentrasi $\mathrm{MgCl}_{2}$ lebih tinggi daripada yang ditetapkan dalam protokol PCR. 
Phytophthora sangat mudah dikenali berdasarkan sporangia yang terbentuk di beberapa jenis umpan daripada sporangia yang didapatkan dari biakan murni pada media selektif. Penggunaan kartu FTA baik sebagai umpan ataupun sebagai pengikat DNA langsung memberikan hasil yang menarik. Namun hasil ini masih memerlukan pengujian lebih lanjut dan mendalam. Kartu FTA ini mempunyai kelebihan karena setelah sampel diaplikasikan, kartu dapat dikeringkan dan disimpan pada temperatur ruangan.

Meskipun amplifikasi PCR dari DNA pada kartu FTA yang berasal dari sampel umpan belum dapat diandalkan menggunakan primer khusus untuk DNA jamur, keberhasilan amplifikasi DNA dari sampel kartu FTA yang dijadikan umpan Phytophthora dengan cara ditinggalkan selama satu minggu di sungai memberikan hasil baru dan menarik. Hal ini membuktikan bahwa matriks kartu FTA tidak memburuk setelah mengalami perendaman dalam jangka waktu yang lama. Optimasi lebih lanjut jelas diperlukan, tetapi teknik ini bisa dikembangkan menjadi suatu teknik monitoring yang berharga. Spesies jamur yang diperoleh dari umpan kartu
FTA membutuhkan identifikasi lebih lanjut menggunakan metode kloning dan sekuensing atau PCR spesies-spesifik.

\section{KESIMPULAN}

Penggunaan kartu FTA sebagai umpan untuk mengikat DNA Phytophthora baik secara langsung atau melalui jenis umpan yang lain membutuhkan lebih banyak penelitian dan validasi.

\section{UCAPAN TERIMAKASIH}

Penelitian ini merupakan bagian dari thesis yang dikerjakan oleh penulis saat melakukan studi di Universitas Tasmania di Hobart, Tasmania Australia. Ucapan terimakasih disampaikan kepada Dr. Caroline Mohammed dan Dr. Morag Glen selaku supervisor baik dalam pekerjaan penelitian maupun dalam penyusunan thesis. 


\section{DAFTAR PUSTAKA}

Boyle, J.S., and Lew, A.M. (1995). An Inexpensive Alternative to Glassmilk for DNA Purification. TIG 11.

Brasier, C., Denman, S., Brown, A., and Webber, J. (2004). Sudden Oak Death (Phytophthora ramorum) Discovered on Trees in Europe. Mycological Research 108, 1107 - 1110.

Britt, J., and Hansen, E. (2009). Trees, soils, streams and rain traps: Intensive sampling leads to recovery of multiple genotypes from hosts of Phytophthora ramorum in Oregon forests. (Portland, OR), pp. S16-S16.

Duran, A., Gryzenhout, M., Slippers, B., Ahumada, R., Rotella, A., Flores, F., Wingfield, B.D., and Wingfield, M.J. (2008). Phytophthora pinifolia sp. nov. Associated with a Serious Needle Disease of Pinus radiata in Chile. Plant Pathology 57, 715-727.

Ferguson, A.J., and Jeffers, S.N. (1999). Detecting Multiple Species of Phytophthora in Container Mixes from Ornamental Crop Nurseries. Plant Disease 83, 1129-1136.

Gardes, M., and Bruns, T.D. (1993). ITS Primers With Enhanced Specificity for Basidiomycetes - Applications to The Identification of Mychorriza and Rusts. Molecular Ecology, pg. 113-118.

Gevens, A.J., Donahoo, R.S., Lamour, K.H., and Hausbeck, M.K. (2007). Characterization of Phytophthora capsici from Michigan Surface Irrigation Water. Phytopatology Vol 97, 421-428.

Ghimire, S.R., Richardson, P.A., Moorman, G.W., Lea-Cox, J.D., Ross, D.S., and Hong, C. (2006). Detection of Phytophthora species in a run-off water retention basin at a commercial nursery in plant hardiness zones $7 \mathrm{~b}$ of Virginia in winter. Phytopathology 96, S40-S40.

Ghimire, S.R., Richardson, P.A., Moorman, G.W., Lea-Cox, J.D., Ross, D.S., and Hong, C.X. (2009). An in-situ baiting bioassay for detecting Phytophthora species in irrigation runoff containment basins. Plant Pathology 58, 577-583.

Glen, M., Tommerup, I.C., Bougher, N.L., and O'Brien, P.A. (2002). Are Sebacinaceae Common and Widespread
Ectomychorrizal Associates of Eucalyptus Species in Australian Forests? Mychorriza 12, 243-247.

Hong, C.X., Gallegly, M.E., Richardson, P.A., Kong, P., and Moorman, G.W. (2008). Phytophthora irrigata, a new species isolated from irrigation reservoirs and rivers in Eastern United States of America. Fems Microbiology Letters 285, 203-211.

Jeffers, S.N., and Martin, S.B. (1986). Comparison of Two Media Selective for and Phytium Species. Plant Disease 70, 1038-1043.

O'Brien, P.A. (2008). PCR Primers for Specific Detection of Phytophthora cinnamomi. Australasian Plant Pathology 37, 69-71. Raeder, U., and Broda, P. (1985). Rapid Preparation of DNA from Filamentous Fungi. Letters in Applied Microbiology, 17-20.

Ristaino, J.B., and Gumpertz, M.L. (2000). New Frontiers in The Study of Dispersal and Spatial Analysis of Epidemics Caused by Species In The Genus Phytophthora. Annual Review of Phytopathology 38, 541-576.

Rogers, C., and Burgoyne, L. (1997). Bacterial Typing: Storing and Processing of Stabilized Reference Bacteria for PCR Without Preparing DNA-An Example of An Automated Procedure. Analytical Biochemistry 247.

Schena, L., Duncan, J.M., and Cooke, D.E.L. (2008). Development and Application of a PCR-based 'Molecular Tool Box' for The Identification of Phytophthora species Damaging Forests and Natural Ecosystems Plant Pathology 57, 64-75.

Schena, L., Hughes, K.J.D., and Cooke, D.E.L. (2006). Detection and Quantification of Phytophthora ramorum, P. kernoviae, $P$. citricola and P. quercina in Symptomatic Leaves by Multiplex Real-time PCR. Molecular Plant Pathology 7, 365-379.

Sechler, K.E., Carras, M.M., Shishkoff, N., and Tooley, P.W. (2009). Detection limit of Phytophthora ramorum-infected Rhododendron leaves using the Cepheid SmartCycler. (Portland, OR), pp. S205-S205. 
Steddom, K. (2009). Detecting Phytophthora in recycled nursery irrigation water in East Texas. (Portland, OR), pp. S124-S124.

Suzuki, S., Taketani, H., Kusumoto, K.I., and Kashiwagi, Y. (2006). Highthroughput Genotyping of Filamentous Fungus Aspergillus oryzae Based on Colony Direct Polymerase Chain Reaction. Journal of Bioscience and Bioengineering 102, 572-574.

Tsao, P.H. (1970). Selective Media for Isolation of Pathogenic Fungi. Annual Review of Phytopathology 8, 157-186.

Tyler, B.M. (2002). Molecular Basis of Rcognition Between Phytophthora Pathogens and Their Hosts. Annual Review of Phytopathology 40, 137-167.
Tyler, B.M., Tripathy, S., Zhang, X., Dehal, P., Jiang, R.H.Y., Aerts, A., Arredondo, F.D., Baxter, L., Bensasson, D., Beynon, J.L., et al. (2006). Phytophthora Genome Sequences Uncover Evolutionary Origins and Mechanisms of Pathogenesis. Science 313, pg. 12611266.

White, T.J., Bruns, T.D., Lee, S., and Taylor, J. (1990). Analysis of Phylogenetic Relationships by Amplification and Direct Sequencing of Ribosomal RNA Genes. PCR Protocols: A Guide to Methods and Applications (New York: Academic Press). 